\title{
Riwayat Pemberian Asi Eksklusif dengan Kejadian Stunting pada Balita Usia 24-60 Bulan
}

\author{
Mayang Chyntaka, Nanda Yansih Putri \\ Program Sarjana Kebidanan STIKES Indramayu \\ Jl. Wirapati Sindang, Kabupaten Indramayu, Jawa Barat \\ Coresponding author : mayangchyntaka87@gmail.com, nandayansiputri@gmail.com
}

\begin{abstract}
ABSTRAK
Latar Belakang: Anak dikatakan stunting ketika pertumbuhan tinggi badannya tidak sesuai. Dampak stunting bukan sekedar tinggi badan anak, kalau anak pendek, ketika remaja dia bisa tumbuh lagi. Anak dikatakan stunting ketika pertumbuhan tinggi badannya tidak sesuai, Dampak stunting bukan sekedar tinggi badan anak, kalau anak pendek, ketika remaja dia bisa tumbuh lagi.

Tujuan: mengetahui hubungan Riwayat Pemberian ASI Eksklusif Dengan Kejadian Stunting Pada Balita di Desa Pabean Ilir Kecamatan Pasekan Kabupaten Indramayu Tahun 2019

Metode: Jenis penelitian ini menggunakan jenis penelitian survey menggunakan pendekatan crosssectional.

Hasil: Hasil penelitian pada kelompok intervensi dan kelompok kontrol pada Kala I diberikan diperoleh bahwa hampir seluruhnya (90,6\%) responden mempunyai riwayat pemberian ASI Eksklusif, lebih dari setengahnya $(63,6 \%)$ balita usia $24-60$ bulan tidak mengalami kejadian stunting.

Kesimpulan: Dari analisis bivariat diketahui bahwa terdapat hubungan yang signifikan antara riwayat pemberian ASI Eksklusif terhadap kejadian stunting di Desa Pabean Ilir Kecamatan Pasekan Kabupaten Indramayu.
\end{abstract}

Kata Kunci : ASI eksklusif, stunting, usia 24-60 bulan

\begin{abstract}
Background: The child is said to be stunted when his height growth is not appropriate. The impact of stunting is not just the height of the child, if the child is short, when he or she can grow up again. The child is said to be stunted when the growth of his height is not appropriate, the impact of stunting is not just the height of the child, if the child is short, when the teenager he can grow again.

Purpose: knowing the relationship of Exclusive Breastfeeding History With Stunting Events In Toddlers in Desa Pabean Ilir Kecamatan Pasekan Kabupaten Indramayu Year 2019

Method: This type of research uses this type of survey research using cross-sectional approach.

Results: The results of studies in the intervention group and control group in Kala I were given that almost entirely $(90.6 \%)$ respondents had a history of exclusive breastfeeding, more than half $(63.6 \%)$ toddlers aged 24-60 months do not experience stunting events.

Conclusion: From the bivariate analysis it is known that there is a significant relationship between the history of exclusive breastfeeding to stunting events in Desa Pabean Ilir Kecamatan Pasekan Kabupaten Indramayu.
\end{abstract}

Keywords : exclusive breast milk, stunting, age 24-60 months

PENDAHULUAN

Permasalahan gizi pada hakekatnya adalah masalah kesehatan masyarakat, namun penanggulangannya tidak dapat dilakukan dengan pendekatan medis dan pelayanan kesehatan saja. Penyebab timbulnya masalah gizi adalah multifaktor, oleh karena itu pendekatan penanggulangannya harus melibatkan berbagai sektor yang terkait ${ }^{(1)}$. 
Stunting didefinisikan sebagai masalah gizi akut yang diakibatkan oleh asupan gizi yang masuk dalam tubuh kurang memenuhi standar dalam kurun waktu lama, menurut Unicef stunting adalah sebagai persentasi anak usia 0 hingga 59 bulan dengan tinggi di bawah minus (untuk kategori sedang dan berat) dan minus tiga (untuk kategori kronis) yang di ukur dari standar pertumbuhan anak dari WHO (2). Anak dikatakan stunting ketika pertumbuhan tinggi badannya tidak sesuai, Dampak stunting bukan sekedar tinggi badan anak, kalau anak pendek, ketika remaja dia bisa tumbuh lagi ${ }^{(3)}$. Ada kesempatan kedua untuk menaikkan tinggi badan. Tapi kalau sudah stunting terkait petumbuhan otak, ketika sudah besar, anak tidak bisa diobati lagi.

Jumlah balita di Kabupaten Indramayu total ada sebanyak 138.188 jiwa, berdasarkan pemantauan Dinas Kesehatan saat ini $29,9 \%$ balita diantaranya menderita stunting. Maka total penderita stunting bejumlah 41.318 balita. Angka tersebut hampir dikategorikan tinggi, sebab stunting digolongkan menjadi beberapa tingkatan kategori. Untuk 10-20 persen tergolong rendah, 20-30 persen sedang, 30-40 persen tinggi dan diatas 40 persen sangat tinggi ${ }^{(4)}$.

Data dari Puskesmas Pasekan tahun 2018 Jumlah balita yang Stunting ada 1751 Jiwa, dari total jumlah balita 2597 Jiwa yang ada di wilayah kecamatan pasekan, adapun Desa yang berada di kecamatan pasekan yaitu: Brondong 428 kasus, karanganyar 388 kasus, pabean ilir 435 kasus, pagirikan 43 kasus, pasekan 279 kasus dan totoran 178 kasus ${ }^{(5)}$.

\section{METODE}

Penelitian ini menggunakan desain study analitik dengan pendekatan crosssectional, atau potong silang yaitu variabel sebab atau resiko dan akibat atau kasus yang terjadi pada objek penelitian diukur atau diteliti secara simultan (dalam waktu yang bersamaan) ${ }^{(6)}$. Populasi ibu-ibu yang mempunyai balita usia 24-60 bulan di Desa Pabean Ilir Kecamatan Pasekan Kabupaten Indramayu, dengan pengambilan sampel menggunakan tehnik accidental sampling berjumlah 66 orang, uji statistik dengan chi square.

\section{HASIL}

\section{Karakteristik Responden}

Tabel 1 Distribusi Frekuensi Menurut Umur Balita, Jenis Kelamin Balita, Pemberian ASI Eksklusif, Kejadian Stunting Pada Balita

\begin{tabular}{ccc}
\hline Variabel & frekuensi & $\%$ \\
\hline Umur Balita : 2 tahun & 20 & 30,3 \\
3 tahun & 19 & 28,8 \\
4 tahun & 18 & 27,3 \\
5 tahun & 9 & 14,6 \\
Jenis Kelamin Balita : Laki -laki & 38 & 57,6 \\
$\quad$ Perempuan & 28 & 42,4 \\
ASI Eksklusif : Ya & 60 & 90,9 \\
Tidak & 6 & 9,1 \\
Stunting : Ya & 24 & 36,4 \\
Tidak & 42 & 63,6 \\
\end{tabular}

Volume 7 Nomor 1. Juli-Desember 2019 
Berdasarkan tabel. 1, dapat diketahui bahwa berdasarkan umur terbanyak balita 2 tahun., setengahnya balita berjenis kelamin laki-laki, hampir seluruhnya responden memiliki riwayat memberikan ASI Eksklusif pada balitanya, lebih dari setengahnya balita tidak mengalami kejadian stunting.

\section{Analisis Bivariate}

Tabel 2. Hubungan Riwayat Pemberian ASI Eksklusif terhadap Kejadian Stunting di Desa Pabean Ilir Kecamatan Pasekan

Kabupaten Indramayu Tahun 2019

\begin{tabular}{cccccccc}
\hline Variabel & \multicolumn{4}{c}{ Variabel Terikat } & & & \\
\cline { 2 - 5 } Bebas & \multicolumn{4}{c}{ Stunting } & \multirow{2}{*}{ Total } & $\boldsymbol{p}$ \\
\cline { 1 - 5 } ASI & \multicolumn{2}{c}{ Ya } & \multicolumn{2}{c}{ Tidak } & & \\
\cline { 2 - 6 } Eksklusif & $\mathrm{f}$ & $\%$ & $\mathrm{f}$ & $\%$ & $\mathrm{f}$ & $\%$ & 0,012 \\
\hline Ya & 19 & 31,7 & 41 & 68,3 & 60 & 100 & \\
Tidak & 5 & 83,3 & 1 & 16,7 & 6 & 100 & \\
& 24 & 36,4 & 42 & 63,6 & 66 & 100 & \\
\hline
\end{tabular}

Berdasarkan tabel 2. diketahui bahwa responden yang mempunyai riwayat pemberian ASI eksklusif dan balitanya tidak mengalami kejadian stunting sebanyak 41 orang $(68,3 \%)$ dan responden yang tidak mempunyai riwayat pemberian ASI eksklusif dan balitanya mengalami kejadian stunting sebanyak 5 orang $(83,3 \%)$.

Berdasarkan hasil uji statistik dengan chi square antara variabel riwayat pemberian ASI eksklusif dengan kejadian stunting diperoleh nilai $p$ value $=0,012$, kemudian dibandingkan dengan nilai $\mathrm{a}=0,05$ sehingga $p$ value $<\mathrm{a}(0,012$ $<0,05)$ maka ha diterima, artinya terdapat hubungan riwayat pemberian ASI eksklusif dengan kejadian stunting di desa Pabean Ilir Kecamatan Pasekan Kabupaten Indramayu.

\section{PEMBAHASAN}

Berdasarkan hasil penelitian diketahui bahwa hampir seluruhnya (90,9\%) responden umumnya memiliki riwayat pemberian ASI Eksklusif pada balitanya.

ASI eksklusif adalah pemberian ASI saja pada bayi umur 0-6 bulan, tanpa tambahan cairan lain seperti susu formula, jeruk, madu, air teh, air putih, dan makanan padat seperti pisang, bubur susu, biskuit, bubur nasi dan nasi tim. Setelah bayi berumur 6 bulan, bayi harus mulai diperkenalkan dengan makanan padat, sedangkan ASI dapat diberikan sampai usia 2 tahun ${ }^{(7)}$.

Air susu ibu (ASI) sebagai makanan alamiah dan makanan yang terbaik yang diberikan oleh seorang ibu kepada bayi yang dilahirkannya. Selain komposisinya yang sesuai untuk pertumbuhan bayi yang bisa berubah sesuai dengan kebutuhan pada setiap saat, ASI juga mengandung zat pelindung yang dapat menghindari bayi dari berbagai penyakit infeksi. Pemberian ASI juga mempunyai pengaruh emosional yang bisa mempengaruhi hubungan batin dan perkembangan jiwa anak serta terdapat pula hubungan yang bermakna antara menyusui dan penjarangan kelahiran. Disamping itu banyak keuntungan lainnya dari pemberian ASI terutama keuntungan terhadap nilai ekonomis ${ }^{\text {(7) (8) }}$.

Berbagai informasi dari beberapa ahli yang mengemukakan hal-hal yang 
mempengaruhi pemberian ASI eksklusif, diantaranya adalah perubahan sosial budaya, ibu bekerja atau kesibukan sosial lainnya, meniru teman, tetangga atau orang lain, merasa ketinggalan zaman jika menyusui bayinya, faktor psikologis, seperti takut kehilangan daya tarik sebagai seorang wanita atau tekanan batin. Faktor fisik ibu seperti ibu sakit, misalnya mastitis, panas dan sebagainya, faktor kekurangan petugas kesehatan, sehingga masyarakat kurang mendapat penerangan atas dorongan tentang manfaat pemberian ASI, meningkatkan promosi susu kaleng sebagai pengganti ASI, penerangan atau informasi yang kurang tepat dan/atau salah justru datang dari petugas kesehatan sendiri yang menganjurkan pengganti ASI dengan susu kaleng ${ }^{(3)}$.

Seiring perkembangan teknologi informasi, memungkinkan responden mudah dalam memperoleh informasi melalui media internet, sehingga responden mampu mengakses berbagai informasi kesehatan terutama berkaitan dengan ASI eksklusif. Berbagai informasi yang positif tentang ASI ekslusif akan meyakinkan responden bahwa pemberian ASI eksklusif memberikan banyak manfaat bagi bayinya sehingga mendorong responden untuk memberikan ASI eksklusif pada bayinya selama 6 bulan ${ }^{(9)}$.

1. Kejadian Stunting

Berdasarkan hasil penelitian dapat diketahui bahwa kurang dari setengahnya $(36,4 \%)$ balita mengalami kejadian stunting dan lebih dari setengahnya $(63,6 \%)$ balita tidak mengalami kejadian stunting.

Stunting adalah perawakan pendek yang timbul akibat malnutrisi yang lama. Stunting pada usia balita biasanya kurang disadari karena perbedaan dengan anak yang tinggi badannya normal tidak terlalu tampak. Stunting baru disadari setelah anak memasuki usia pubertas atau remaja. Hal ini merugikan karena semakin terlambat disadari, semakin sulit mengatasi stunting.

Masalah balita pendek menggambarkan masalah gizi kronis, dipengaruhi dari kondisi ibu/calon ibu, masa janin dan masa bayi/balita, termasuk penyakit yang diderita selama masa balita. Dalam kandungan, janin akan tumbuh dan berkembang melalui pertambahan berat dan panjang badan, perkembangan otak serta organ-organ lainnya. Kekurangan gizi yang terjadi dalam kandungan dan awal kehidupan menyebabkan janin melakukan reaksi penyesuaian.

Secara paralel penyesuaian tersebut meliputi perlambatan pertumbuhan dengan pengurangan jumlah dan pengembangan sel-sel tubuh termasuk sel otak dan organ tubuh lainnya. Balita pendek (stunting) dapat diketahui bila seorang balita sudah diukur panjang dan tinggi badannya, lalu dibandingkan dengan standar dan hasilnya berada di bawah normal. Secara fisik balita akan lebih pendek dibandingkan balita seumurnya.

2. Hubungan Riwayat Pemberian ASI Eksklusif Terhadap Kejadian Stunting

Berdasarkan hasil penelitian dapat diketahui bahwa terdapat hubungan yang signifikan antara riwayat pemberian ASI Eksklusif dengan kejadian stunting. 
Pada keadaan normal, tinggi badan tumbuh seiring dengan pertambahan umur. Pertumbuhan tinggi badan tidak seperti berat badan yang relatif kurang sensitif terhadap masalah kekutangan zat gizi dalam waktu yang pendek, karena pengaruh kekurangan zat gizi terhadap tinggi badan akan nampak dalam waktu yang relatif lama.

Asupan gizi yang mencukupi pada awal kehidupan bayi di awal kehidupan menjadi penentu pertumbuhan anak. Pemberian ASI eksklusif selama 6 bulan dapat berpengaruh terhadap kejadian stunting. Ibu setelah melahirkan normal memiliki kesempatan untuk memberikan kolostrum namun bagi ibu yang melahirkan dengan operasi caesar diperlukan peran tenaga medis dan anggota keluarga lain agar kolostrum dapat diberikan kepada bayinya. Kolostrum merupakan cairan emas yang encer berwarna kuning dan mengandung sel hidup yang dapat mmembunuh kuman penyakit serta obat untuk membersihkan saluran pencernaan dari kotoran bayi dan membuat saluran pencernaan bayi siap menerima asupan ASI selanjutnya.

Bayi mendapatkan manfaat yang besar dari ASI. Selain mendapatkan nutrisi yang dibutuhkan bayi, ASI juga berperan penting dalam melindungi dan meningkatkan kesehatan bayi. Pemberian ASI eksklusif dapat mengurangi resiko bayi kekurangan gizi, karena ASI adalah makanan alamiah yang disediakan untuk bayi dengan komposisi nutrisi yang sesuai untuk perkembangan bayi. Jika bayi tidak diberikan ASI dan diganti dengan susu formula, maka bayi tidak akan mendapatkan kekebalan, serta akan mengalami kekurangan gizi. Dengan tidak adanya zat antibodi, maka bayi akan mudah terkena berbagai macam penyakit dan meningkatkan resiko mengalami stunting.

Hasil penelitian yang dilakukan Faraissa Hasanah tahun 2016 yang berjudul hubungan pemberian ASI eksklusif dengan kejadian stunring dipeorleh hasil penelitian nilai $\mathrm{p}=$ 0,034 yang berarti terhadap hubungan yang signifikan antara pemberian ASI eksklusif dengan kejadian stunting. Hal ini menunjukkan bahwa ASI eksklusif merupakan faktor yang mencegah terhadap kejadian stunting pada balita (10).

ASI Eksklusif memiliki kontribusi yang besar terhadap tumbuh kembang dan daya tahan tubuh anak. Anak yang diberi ASI eksklusif akan tumbuh dan berkembang secara optimal karena ASI mampu mencukupi kebutuhan gizi bayi sejak lahir sampai umur 24 bulan yang diperlukan untuk pertumbuhan, perkembangan dan kelangsungan hidup bayi $^{(7)}$.

\section{KESIMPULAN}

Terdapat hubungan yang signifikan antara riwayat pemberian ASI Eksklusif terhadap kejadian stunting di Desa Pabean Ilir Kecamatan Pasekan Kabupaten Indramayu.

\section{DAFTAR PUSTAKA}

1. Almatsier Sunita, 2002. Prinsip Dasar Ilmu Gizi. Gramedia Pustaka Utama, Jakarta. 
2. Arisman MB, 2009. Buku Ajar Ilmu Gizi : Gizi Dalam Daur Kehidupan. EGC, Jakarta.

3. Buletin Jendela, 2018. Data dan Informasi Kesehatan.

4. Dinas Kesehatan Provinsi Jawa Barat 2018. Profil Kesehatan Provinsi Jawa Barat.

5. Dinas Kesehatan Kabupaten Indramayu. 2018. Data Laporan Gizi. Indramayu: Dinas Kesehatan Kabupaten.

6. Puskesmas Pasekan. 2018. Laporan Data Balita Stunting Tahun 2018.

7. Global Nutrition Report, 2014. Action and Accountability To Accerate The Word's Progres On Nutrition.

8. Handayani Is. Hubungan Antara Sosial Ekonomi Keluarga dengan Status Gizi Balita Indonesia (diunduh 10 Juli 2019).

9. Irianto Kus dan Kusno Waluyo 2004. Gizi dan Pola Hidup Sehat Untuk Para Pelajar, Para Mahasiswa, Para Eksekutif, Umum, Yrama Widya, Bandung.

10. Maryam Siti 2015. Gizi Dalam Kesehatan Reproduksi, Salemba Medika, Jakarta.

11. Notoatmodjo, 2012. Promosi Kesehatan Perilaku Kesehatan Masyarakat. Rineka Cipta, Jakarta.

12. Riset Kesehatan Dasar (Riskesdas) 2018, Kementrian Kesehatan Indonesia.

13. Roesli, U. 2009. Mengenal ASI Eksklusif. Jakarta :Trubus Agriwijaya

14. Putri Rona Firmana, 2015. Faktor-faktor yang Berhubungan dengan Status Gizi Anak Balita di Wilayah Kerja Puskesmas Nanggalo Padang. Jurnal.fk.unand-Vol 4, No1.

15. Soetjiningsih, 1998. Tumbuh Kembang Anak. EGC, Jakarta.

16. Supariasa IDN, Bakri B, Fajar I 2014. Penialaian Status Gizi. Penilaian Status Gizi, EGC, Jakarta.

17. WHO 2014, WHO Global Nutrition Target. Stunting Policy Brief. Geneva 